\title{
Śladem romantycznej kreacji bohatera w chorwackiej poezji końca XX wieku. Od wampira do konsumenta
}

ABSTRACT. Pieniążek-Marković Krystyna, Śladem romantycznej kreacji bohatera w chorwackiej poezji końca XX wieku. Od wampira do konsumenta (Tracing the Romantic creation of character in Croatian poetry of the end of the 20th century. From vampire to consumer). „Poznańskie Studia Slawistyczne” 1. Poznań 2011. Rys Press, pp. 207-228. ISSN 2084-3011.

One of the distinctive traits of Romantic literature was its frenetic feverishness and frightening otherness, the embodiment of which was, among many other beings, the vampire. This character in neo-Romantic contexts was sometimes invoked by the representatives of Croatian poetry of the late twentieth century. However, in its different currents it performed a different task. War and martyrdom poetry collected in the anthology $U$ ovom strašnom času used the specter for the creation of a portrait of the enemy, while using the familiar clichés of Renaissance variant of Croatian romanticism. Branko Maleš' vampiric themes merge into an indivisible whole with references to contemporary consumerism and co-create an ironic self-portrait of a postmodern neo-Romanticist. Maleš reaches for the themes of romantic strangeness and deconstructs them in a ludic manner.

Keywords: vampire, consumption, Croatian poetry, war lyric poetry, Maleš, neo-romanticism.

Chorwacka poezja schyłku XX wieku stanowiła - choćby mimowolną - reakcję na traumatyczną rzeczywistość, na stan po katastrofie i rozpad dotychczasowego świata. Dokumentowała indywidualne 
sposoby radzenia sobie w sytuacji zbrojnego konfliktu i powojennych transformacji. Spektrum odpowiedzi na gwałtowne przemiany w kraju jest zróżnicowane, a za jego skrajne propozycje można uznać, z jednej strony, mocne zanurzenie w otaczającym świecie, aż po udział w walce, a z drugiej - różnorodne formy ucieczki od zbyt boleśnie doświadczanej realności. Nowe uwarunkowania przynaglały do zawiązywania z nimi nowych podmiotowych relacji oraz do poszukiwania języka adekwatnie odzwierciedlającego stany wewnętrzne i możliwość komunikacji ze światem zewnętrznym. Nowe często okazywało się jednak starym, a niekiedy przestarzałym. ,Wojna obronna”, jak głosi chorwacka nazwa niedawnego zbrojnego konfliktu, sprzyjała odnowieniu paradygmatu romantycznego. Niosła kompleks patriotyczno-martyrologiczno-mesjanistycznych pierwiastków charakterystycznych dla romantycznego sposobu myślenia i przeżywania świata. Bohater realizujący swój obywatelski obowiązek w zbrojnym czynie wydaje się naturalnym konstruktem literatury powstającej w kontekście spełniającego się snu o niepodległej ojczyźnie. W nowo-starą retorykę włączono tak sztandarowe wyznaczniki narodowej tożsamości jak katolicyzm, naród wybrany, przedmurze chrześcijaństwa, zakorzenienie w starożytnej cywilizacji (kiedyś teorie iliryjskie, dzisiaj irańskie ${ }^{1}$ ) itp. odwołania identyfikacyjne.

Konflikt zbrojny spowodował ożywienie romantycznego, co w przypadku Chorwacji oznacza także odrodzeniowego paradygmatu patriotycznego oraz romantycznego wzorca literackiego. Odnowienie oznacza równocześnie wzbogacenie; chorwacka poezja martyrologiczna z końca XX wieku wprowadza bowiem do literatury zjawy, widma, duchy i upiory nieobecne w jej dorobku z pierwszej połowy XIX wieku ze względu na brak ,czarnego" romantyzmu czy fantastyki grozy. Do bardziej znanych postaci uosabiających antropomorficzne zło, charakterystyczne dla tego ciemnego nurtu romantyzmu, należy wampir. U pisarzy z zachodniej Europy pojawiał się on w tekstach będących równocześnie egzemplifikacją romantycznego zainteresowania egzotyką, Orientem (Wschodem oraz Południem), folklorem. Świadectwem

1 Comp. M. Dyras, Re-inkarnacje narodu. Chorwackie narracje tożsamościowe w latach dziewięćdziesiatych XX wieku, Kraków 2009, rozdział: Chorwacka etnogeneza a narracje o tożsamości narodowej. 
tego splotu romantycznych inspiracji jest słynna mistyfikacja literacka romantyka francuskiego, Prospera Mériméego, wydana anonimowo w roku 1827 Guzla albo wybór poezji iliryjskich zebranych w Dalmacji, Bośni, Kroacji i Hercegowinie ${ }^{2}$. To właśnie Słowiańszczyznę południową oraz Grecję najczęściej wskazuje się jako terytoria narodzin wiary w powstające z grobu upiory. Współczesny wampir, wyłaniający się z chorwackiej poezji po 1991, nadal straszy na obszarze wskazanym przez tytuł zbioru Mériméego, choć zmienił on nieco swoje dzisiejsze oblicze. Oto jedno z nich:

spodobe s mrtvačkim glavama umjesto srdaca

proklete od Boga

plaze mojom Hrvatskom

niža bića iz prapovijesti

nečista od vonja smrti

rukuju se nožem kao mjerilom svijeta.

Razbacani hrvatski udovi

i prerezana grla

njihov su trag

genocidni vampiri šiljatih lubanja

pijani se valjaju hrvatskim zgarištima

aveti u mraku bezumlja

Otvori se sveta zemljo hrvatska

budi im grob

jednom za svagda stwory z trupimi głowami

zamiast serc

przeklęte przez Boga

pełzną moją Chorwacją

niższe istoty z prehistorii

nieczyste smrodem śmierci

posługują się nożem jak miarą świata.

Rozszarpane ciała Chorwatów

z poderżniętymi gardłami

to ich ślad

niszczycielskie wampiry

o spiczastych czaszkach

pijani tarzają się po chorwackich

pogorzeliskach

upiory w mroku szaleństwa

Otwórz się święta ziemio chorwacka bądź dla nich grobem

raz na zawsze

(Ljerka Car Matutinović, Otvori se sveta zemljo hrvatska - Otwórz się święta ziemio chorwacka ${ }^{3}$ ).

2 Za: M. Janion, Wampir. Biografia symboliczna, Gdańsk 2008, s. 26.

3 Lj. Car Matutinović, Otvori se sveta zemljo hrvatska, w: U ovom strašnom času, red. I. Sanader, A. Stamać, Split 1992, s. 16; polski przekład: Otwórz się święta ziemio chorwacka, w: I. Sanader, A. Stamać, W tej strasznej chwili. Antologia wspótczesnej wojennej liryki chorwackiej, przeł. M. Kordowicz, Warszawa 1996, s. 20. Comp. J. Kornhauser, Chorwacka poezja martyrologiczna po 1991 roku i stereotypy narodo- 
Poezja spod znaku wydanej także w Polsce antologii $W$ tej strasznej chwili, z której pochodzi cytowany wiersz Ljerki Car Matutinović, sięga po obrazy niewinnych ofiar: ojczyzny (domoviny), dwóch szczególnych miast - Vukovaru i Dubrownika oraz obrońców kraju, najczęściej młodych chłopców. Młodzieńczy wiek i obligatoryjnie wiązana z nim niewinność determinują chorwackich bojowników (chorwackie dzieci) do rangi najcenniejszego daru z życia składanego na ołtarzu ojczyzny. W Przedmowie redaktorzy tomu odwołują się do typowego dla tekstów dziewiętnastowiecznych, odrodzeniowo-romantycznego patosu skoncentrowanego na wartości ojczystej mowy, w której zawiera się i wyraża wielki, patriotyczny, męczeński duch chorwackiego narodu, narodowa suwerenność i tożsamość. Wybór wierszy nazywany jest, ,bukietem tragicznie zerwanych duchowych róż”, śladem, który poeci ,zostawili na chorwackiej niwie duchowej, przesiąkniętej krwią, cierpieniem i rozpaczą”, „są tym najlepszym, co wrażliwość poetycka w tych ciężkich historycznych dniach zapisała głębią myśli, wrażliwością uczuć i pięknem języka”, ,przyczyniły się do afirmacji chorwackiego słowa literackiego, które w ten sposób wyszło z («zamkniętych»?) literackich i książkowych układów”, „liryka wojenna świadczy też o poziomie swego języka ojczystego”, ,poeci chorwaccy są duszą swej ziemi"4. Cytowane fragmenty zgromadzone zostały na zaledwie dwóch stronach przedmowy do drugiego wydania, które otrzymaliśmy w niedoskonałym (co podkreśla m. in. Julian Kornhauser w artykule Chorwacka poezja martyrologiczna po 1991 roku i stereotypy narodowe) polskim przekładzie. Autorzy wyboru korzystaja $\mathrm{z}$ retoryki stosowanej $\mathrm{w}$ dziewiętnastowiecznych tekstach o charakterze dydaktycznym i programowo-propagandowym oraz odwołują się do teorii głoszących, że o odrębności narodowej stanowi odrębność językowa.

Wojenna i „noworomantyczna” (z końca XX wieku) propedeutyka wiedzy o narodzie chorwackim budowana jest na zasadzie prostych opozycji wobec wrogów, czyli najbliższych słowiańskich krewnych i sąsiadów oraz w opozycji do iliryjskich wizji wspólnotowych. Dale-

we, w: idem, Świadomość regionalna i mit odrębności (o stereotypach $w$ literaturze serbskiej i chorwackiej), Kraków 2001.

${ }^{4}$ W tej strasznej chwili..., op. cit., s. 7-8. 
kie od jasności i jednoznaczności - przypomnijmy za Joanną Rapacką - chorwackie dziewiętnastowieczne koncepcje słowiańskiej jedności, rozdarte „między pragnieniem budowy szerokiej wspólnoty a dążeniem do zachowania odrębności"', operowały dwiema koncepcjami narodu, w sensie politycznym (obejmującym Królestwo Dalmacji, Chorwacji i Slawonii, chodziło bowiem przede wszystkim o zjednoczenie historycznych ziem chorwackich) oraz kulturowym, otwartym dla wszystkich Słowian południowych, „którzy będą gotowi przyjąć wspólny język literacki i w języku tym budować gmach wspólnej kultury”. Idea wspólnego organizmu państwowego zaczęła triumfować dopiero około 1848 roku, jednak spotkała się ze słabym oddźwiękiem wśród innych narodów. Projekty wzajemności słowiańskiej u schyłku XX wieku zostały zastapione przez potrzebę wyodrębnienia - zwłaszcza kulturalnego i cywilizacyjnego; potrzebę charakterystyczną dla okresów wojny i procesów odradzania się państwowości. Niemożliwa do zaprzeczenia i pokonania rzeczywista sąsiedzka bliskość etnogenetyczna, językowa i geograficzna (na linii horyzontalnej), a nawet konieczność dzielenia tego samego terytorium, rekompensowane są poprzez eksploatowanie różnic duchowych, mentalnych, czemu najlepiej służy hiperbolizowanie odległości na linii wertykalnej i czasowej.

Pojawiające się wampiry wyłaniają się z otchlani i z prehistorii, są istotami niższymi, pełzającymi, cuchnącymi, ludobójczymi (genocidni). Licznym degradującym oznacznikom przeciwstawiony jest jeden o charakterze zbiorczym, wobec którego całkowicie zbędne staja się wszelkie określenia dodatkowe: święta ziemia chorwacka. Sakralizacja jest aktem wznoszącym, sytuującym na najwyższym punkcie osi wertykalnej (niebo) i maksymalnie uwypuklającym oddalenie od upiornych czeluści. Świętych znamy także jako postacie o łagodnym obliczu (vs. niszczycielski), a po śmierci ich ciała nierzadko zamiast ulegać rozkładowi zachowują nienaruszony wygląd, niekiedy nawet pięknieją i roztaczają przyjemny aromat (vs. smród). Wiara we wstawiennictwo świętego owocuje cudami. Takie zdolności cudotwórcze

J. Rapacka, Godzina Herdera. O Serbach, Chorwatach i idei jugostowiańskiej, Warszawa 1995, s. 32.

6 Ibidem, s. 33. 
posiada także święta ziemia chorwacka. Przeciwnie do znanych historii o wampirach, które, śmiertelnie wyczerpując swoje ofiary, same pozostają nieśmiertelne, chorwacka ziemia nie tylko nie ulega skażeniu jadem, podobnie zresztą jak zachowujący niewinność jej mieszkańcy, lecz ma moc uzdrawiająca, uwalniającą od wampiryzmu, oferującą wieczny spoczynek ${ }^{7}$.

Wampiryczna, przerażająca romantyczna cudowność ,z tamtego brzegu" miała - zdaniem Marii Janion - wstrząsnąć posadami kultury klasycystycznej ${ }^{8}$. W poezji wojennej podporządkowana jest celom narodowym, przy czym nie tylko zachowuje znamiona „mroku inności”, ale „niepokojącą obcość” ${ }^{10}$ znacznie pogłębia, transformując niepokój $\mathrm{w}$ przerażenie i grozę. Wampir nie jest tu jednym $\mathrm{z}$ fantazmatów śmierci umożliwiającym kontakt z tym, co odrzucone i powracające w postaci prześladowczych wizji, lecz uosabia nieludzkie oblicze najeźdźcy i mordercy. W liryce wojennej wampiryzm jawi się jako zjawisko uniwersalne, ponadczasowe i cykliczne, a nawrotom ataków wampirów sprzyjają okresy krwawienia Chorwatów i Chorwacji. Przypadki wampiryzmu nie ograniczają się wówczas do odosobnionych jednostek zawieszonych między życiem i śmiercią, stając się właściwością agresorów (narodu): „Krvožedne horde” (krwiożercze hordy - Ernest Fišer, s. $25^{11}$ ). Zwampiryzowane masy, choć uczestniczą w wydarzeniach z końca XX wieku, wykazują wiele wspólnego z relacjami na temat wampirów pochodzącymi jeszcze z XVIII wieku. Maria Janion przypomina istotne $\mathrm{w}$ tym kontekście fragmenty poświęconych im dzieł: Józef Maksymilian Ossoliński w Wieczorach badeńskich, czyli Powieści o strachach i upiorach pisał o mrowiu i kupach upiorów, zaś Pierre Gripari, prezentując rodowód wampira, jako kraj szczególnie nasycony wampirami wskazuje właśnie Serbię, ale też Polskę i Ukrainę.

\footnotetext{
7 Koncepcja ta zaprzecza tradycyjnym poglądom, przedstawionym w 1764 roku przez Woltera, głoszącym, że przez samo pochowanie w katolickiej ziemi prawosławny (i na odwrót) staje się wampirem. Za: M. Janion, Wampir..., op. cit., s. 26.

8 M. Janion, Niesamowita Słowiańszczyzna, Kraków 2006, s. 61.

9 Ibidem, s. 62.

10 Ibidem.

11 Numery stron w nawiasach, jeżeli nie podano inaczej, odnoszą się do chorwackiego wydania: U tom strašnom času..., op. cit.
} 
Również narrator opowieści Aleksego Tołstoja ,przedstawia jako fakt ogólnie znany to, że w wieku XVIII całe wsie serbskie bywały zwampiryzowane"12. Ponowoczesna, nadciągająca ze Wschodu i Południa śmiercionośna epidemia może być zatem uznana za kolejne wcielenie mitu. Jego współczesna wersja odwołuje się do niesprecyzowanych prehistorycznych korzeni zjawiska, jednak dla realizacji celów aktualnych dzisiejsze wampiry sięgają także po najnowsze osiagnięcia techniki (na przykład po precyzyjne, skomputeryzowane samoloty, s. 44).

W tradycji wampiry często podlegały demonizacji, podobnie dzieje się w tekstach zamieszczonych w antologii. Demoniczne wampiry nie wychodzą z grobów tylko dlatego, że wyczuły krew, ale także dlatego, żeby ranić i zabić. Wampir, krwiożerca czy hiena - jako metaforyczny synonim wroga - bywa też zastępowany innymi określeniami: „rušitelji s istoka i juga" (burzyciele ze wschodu i południa), „troprsti barbari” (trójpalczaści barbarzyńcy - Jevrem Brković, s. 15), „zločinci” (złoczyńcy - Ernest Fišer, s. 25; Slavko Mihalić, s 48), „ubojice” (zabójcy - Dubravko Horvatić, s. 29), „dusi gangsterske države” (duchy gangsterskiego państwa - Slavko Jendričko, s. 33), „crni pas” (czarny pies - Dražen Katunarić, s. 38), ,srpski zlotvori”, „osmanlijski vazali”, „Tatare” (serbscy złoczyńcy, osmańscy wasale, Tatarzy-Mihalić, s. 45), „grabežljivci” (drapieżcy - Mihalić, s. 48). Określeniom tym najczęściej towarzyszą ekspresyjne opisy znęcania się na ciałami ofiar. Język wojenno-martyrologiczny konsoliduje zaspokajanie wampirycznego łaknienia w obrazie zezwierzęconego, dzikiego krwiopijcy jakby wyłaniającego się z niesamowitych opowieści, magicznego i okrutnego świata wyobraźni ludowej: ,grabežljivci razdvojenih papaka / u šumi veprovoj / blaguju našu krv / sijeku potiljke, otvaraju nam utrobe / lapću jezikom i oblizuju se" (drapieżcy z rozdwojonymi kopytami / w lesie wieprzy / spożywają naszą krew / sieką potylice, otwierają nam wnętrzności / chłepcąjęzykiem i oblizują się - Dražen Katunarić, s. 38). Szczególnie często pojawia się jeden z ważniejszych rytuałów antropofagicznych, czyli obraz wyjmowanych z ludzkich piersi żywych serc - ośrodka układu krwionośnego (s. 47, s. 49). Atrybutem krwiopijcy nie są już tylko siekacze czy pazury o monstrualnych rozmiarch, ale „kolci i ma-

12 M. Janion, Wampir..., op. cit., s. 8-9. 
sno ulašteni noževi” (pale i tłusto wypolerowane noże - Boris Biletić, s. 11), ,puščane cijevi” (rury karabinów - Dubravko Horvatić, s. 29), „sjekira” (siekiera - Slavko Jendričko, s. 33), „nož među zubima” (nóż w zębach - Mihalić, s. 45) a nawet „zrakoplovi-ubojice” (samoloty-zabójcy, za których sterami zasiadają zamaskowani piloci - szczury i czarne wdowy ${ }^{13}$, po wylądowaniu udający się do zajazdów, gdzie krwią gaszą pragnienie - „naručuju pića. U čašama krv.” - zamawiają napoje. W szklankach krew - Slavko Mihalić, s. 44).

Wampir, osmański wasal i brodaty czetnik to w istocie ten sam wróg, można powiedzieć, że wymienione określenia współtworzą ponadindywidualny portret najeźdźcy. Trupia czaszka jest zarówno symbolem wynurzającego się z grobu upiora, jak i rozpowszechnionym w czasie drugiej wojny światowej symbolem widniejącym na sztandarach czetników. Broda i trupia czaszka stają się synekdochicznym znakiem jednego mordercy i agresora. W kontekście konfliktu z lat 90. XX wieku druga wojna światowa pojawia się jako jedna z ważniejszych iskier zapalnych oraz jako matryca komunikacyjna. Chorwacka badaczka Dubravka Oraić Tolić wampirem nazywa „zupioryzowaną utopię Jugosławię” oraz nieprzepracowaną w powojennej Jugosławii przeszłość, zwłaszcza historię drugiej wojny światowej, która jak żywcem pochowany upiór wyłoniła się z tymczasowego grobu, zakażając swym jadem i doprowadzając do samego konfliktu ${ }^{14}$. Także Julian Kornhauser, wypowiadając się na temat zgromadzonej w omawianej antologii chorwackiej poezji martyrologicznej, w wykorzystywanych przez autorów typowych przeciwstawieniach dostrzega reanimowanie historycznych stereotypów, odwołujących się zarówno do „wojny partyzanckiej, jak i bogatego arsenału komunistycznych środków perswazji, jakimi przepełniona była

13 Czarne wdowy to gatunek jadowitych pająków, często mylonych z karakutami, także jadowitymi pająkami, które zamieszkują m.in. Chorwację. Mihalić odwołuje się zapewne równocześnie do pierwotnego, jak i do metaforycznego znaczenia terminu.

14 ,Za jugoslavensko-srbijansku stranu rat iz 1991. prepisivanje je rata iz 1941. Povod, zaraćene strane, vrsta i ciljevi rata sve su to citati iz Drgog svjetskog rata. Rat je počeo simulacijom ugroženosti srpske zajednice od navodnih «ustaša». Citirane su zaraćene strane iz prošloga rata. Mi Srbi smo «četnici», a oni Hrvati su «ustaše». (...) Ispod ovih citatnih ciljeva, ovoga simulacruma Drugoga svjetskog rata, leži, kao u krvavom rebusu, skrivena sljedeća jednostavna i tragična istina: povampirena utopija Jugoslavija”. D. Oraić Tolić, Književnost i sudbina, Zagreb 1995, s. 12-13. 
literatura po 1945 roku. Tym razem jednak, jakby na zasadzie rewanżu, odwraca się funkcjonujący wówczas schemat: okrutni chorwaccy ustasze - dobrzy serbscy wojownicy. Świadomie przy tym ucieka się od prawdy historycznej, od przyczyn konfliktu (...). Rzeczywis-tość faktów zastępuje się wybuchem emocji, w której górę bierze klisza historyczna ludowej proweniencji"'15. Ta hiperuczuciowość, pierwiastki folkloru, dziwiętnastowieczne mesjanistyczne oraz późniejsze klisze martyrologiczne, charakterystyczne dla współczesnej kultury eksponowanie wizualizacyjnych mocy ukrytych w obrazach tekstowych przyczyniają się do powstania kiczowatych wizji, a nawet - posługując się językiem Marii Janion - kiczowatej „straszności”. Janion mówi o kiczu, kiedy - jak w przypadku cytowanych utworów - dochodzi do ,użycia motywów wampiryzmu nie przetrawionego w tyglu sztuki, nie poddanego obróbce artystycznej, lecz często pożytkowanego jedynie dla budzenia grozy i przerażenia oraz wzmagania tych efektów za wszelką cenę"16.

Zupełnie inne wcielenie upiora w przesyconym kanibaliczno-biesiadną atmosferą tomiku Biba Posavec ${ }^{17}$ proponuje Branko Maleš (poeta debiutujący pod koniec lat 70.). Nawiązuje on do tematyki wojennej, są to jednak uwagi ponadczasowe, w których brak jednoznacznych odniesień do konfliktu z lat 90., a co najważniejsze, nie odnajdziemy w nim prostych schematów i jednoznacznych ocen. Podobnie jak w antologii W tej strasznej chwili pojawia się u tego poety motyw chłopców-darów ofiarnych, umiłowanych dzieci, które przy ,pierwszym chłodniejszym zmierzchu, przy smętnych dźwiękach fujarki, zostają ofiarowane bykowi zimy"18. Na uwagę zasługuje tu przesunięcie w obszarze winnego: nie są nim krwiożercze napadające wampiry, lecz rodzimi władcy.

W poetyckim świecie Branka Maleša rywalizacja między państwami, zdobywanie nowych terytoriów jest także prezentowane w odwołaniu

15 J. Kornhauser, op. cit., s. 105.

16 M. Janion, Wampir ..., op. cit., s. 10.

17 B. Maleš, »biba posavec«, Zagreb 1996. Cytując utwory z tego tomu podaję skrót BP oraz numer strony.

18 ,ti dječaci koji su / bili lijepi i od / živog srebra / vjerojatno su / bili / cvjetovi neke blage / boje / koje bi / kraljevi / nosili ispod srca / ili / bi ih žrtvovali / biku zime / za prvog hladnijeg / sumraka / uz / prilično / tugaljivih frula”. B. Maleš, Trcikster, Zagreb 1997, s. 26. Dalej w tekście, cytując utwory z tego tomu, podaję w nawiasie skrót T. 
do wyobraźni wampirycznej czy kanibaliczno-wampirycznej, jednak nie jako proces jednostronnego mordowania ofiar, lecz wzajemnego pożerania czy raczej jako obustronna gotowość do zjedzenia się, na szczęście nie zaktywizowana. Diametralnie odmienny jest także język tej poezji, nie tylko pozbawiony złudzeń o skrywanym i przekazywanym duchu narodu, ale dekonstruujący jakąkolwiek narrację, która usiłowałaby posługiwać się językiem jako orężem. Patos i wzniosłość zastępuje więc rodzaj infantylno-szaleńczego, bezładnego, niegramatycznego słowotoku, kierującego ku sferom prymitywnym, pierwotnym, irracjonalnym. W poezji Maleša jakby ożywał język szalonej Karusi z Romantyczności:

da su htjeli pojeli bi nas! (...) da su mogli pojeli bi nas! (...) nisu nas pojeli kao neki gadan ručak koji zuji (...)

da smo htjeli mogli smo ih pojesti a nismo

a bili smo goli

i spremni za neki gadan ručak svega uz pripjev prilog prijedlog gdyby chcieli, zjedliby nas! (...) gdyby mogli, zjedliby nas! (...) nie zjedli nas jak jakiegoś wstrętnego brzęczącego obiadu (...) gdybyśmy chcieli, mogliśmy ich zjeść nie zjedliśmy a byliśmy nadzy

i gotowi na jakiś wstrętny obiad wszystkiego z przyśpiewką, przystawką,

(O klopi i državi-O jedzeniu i państwie, BP, s. 5-7).

Byliśmy nadzy, nieuzbrojeni i bezbronni, wystawieni na pożarcie - te informacje z pierwszych wersów kilkuczęściowego utworu mogą stwarzać pozór wypowiedzi charakterystycznej dla liryki lamentacyjnej, ale już od trzeciego wersu staje się zrozumiałe, że nie mamy do czynienia z płaczem nad losami narodu i kraju, mimetyzmem czy wojennym dokumentem. Opozycyjne wspólnoty nie są skonkretyzowane, jacyś „my” i ,oni” właściwie nie różnią się między sobą, a przywołane stany, zjawiska czy rzeczy, eksplikowane są „same przez się"19. W tym poetyckim świecie nie obowiązują zasady logiki czy precyzji, zasadą organizującą tekst wydaje się zadziwienie i zaskoczenie. Jedną z cech

19 „zujali smo oko sreće jer smo zujali (...) bili smo goli jer smo bili goli” - BP, S. 5 . 
przedstawionego świata są nieustanne metamorfozy. Poeta kreuje nierzeczywistość, w której niemal na sposób romantyczny każda rzecz jest równocześnie czymś innym ${ }^{20}$, świat złożony z elementów wzajemnie się przenikających, poplątanych, trudnych lub niemożliwych do wydzielenia, przypominający rizomatyczną sieć rozgałęzień, jak chciałoby się powiedzieć w ponowoczesnym języku Deleuze'a/ Guattariego, płynny świat Baumana lub też „,wolny” świat romantyka, który ,programowo nie znosił niewoli, nawet w złagodzonej formie ładu i porządku" 21 . Każdy z tych światów: splątany, płynny i „wolny” tworzy niepodzielnąjedność. O całości marzyli romantycy i prezentuje ją współczesny poeta pragnący łączyć przeciwieństwa: ,,baka i unuk! / PIJETAO I ZMIJA! / crno i bijelo i to triput! / svi se moraju vjenčati! / zec i sporost! / blijeda mjesečina / i žarko sunce / koje pali" (babcia i wnuk! / KOGUT I WĄŻ! / czarne i białe i to trzykrotnie! / wszyscy muszą się pobrać! / zając i powolność! / blada poświata księżyca / i gorące słońce / które pali - T, s. 23). Formą dla tego uniwersum lub jego osią ogniskująca jest sam mówiący podmiot: „sve će biti u meni” (we mnie będzie wszystko - BP, s. 9). Cytowane fragmenty równie dobrze możemy uznać za świadectwa dekonstrukcji nowoczesnej (i neoromantycznej) suwerenności.

Bohater tej poezji, także Branko Maleš, kilkakrotnie przywołany z imienia i nazwiska oraz z rzeczywistą datą urodzin autora, sam staje się wampirem-kanibalem: ,,volio sam bibu posavec! / kad sam je pojeo / mislili su da sam / japanac / a ja sam tada bio / branko maleš, 18. 1. 1949!" (kochałem bibę posavec! / kiedy ją zjadłem / myśleli że jestem japończykiem / a ja byłem wówczas brankiem malešem, 18. 1. 1949! - BP, s. 62). Autobiografizm ${ }^{22}$ traktowany jest jako cecha charakterys-

20 ,Żaden prawdziwy romantyk nie powie, że «naprawdę» było tak a tak, bo «naprawdę» zawsze jest dla niego równocześnie tak i inaczej. Tu jest punkt wyjścia dla romantycznego rozwiązania rachunków ze światem, czyli dla ironii”. M. Piwińska, Złe wychowanie. Fragmenty romantycznej biografii, Warszawa 1981, s. 67.

21 Ibidem, s. 60.

22 Alina Kowalczykowa pisze o skłonności do uzewnętrzniania najbardziej prywatnych przeżyć (A. Kowalczykowa, hasło: Romantyzm, w: Słownik literatury polskiej XIX wieku, red. J. Bachórz, A. Kowalczykowa, Wrocław - Warszawa - Kraków 1994, s. 837), natomiast Marta Piwińska o demonstrowaniu ,ja” (op. cit., s. 60) i egocentrycznym zwrocie (s. 57): ,W pewnej chwili zjawia się bohater i mówi o sobie «ja», a jego 
tyczna twórczości romantycznej, także, a może zwłaszcza ten - jak $\mathrm{u}$ chorwackiego poety - w wydaniu ironicznym i to zarówno wobec samego siebie, jak i wobec gatunku. Maleš sugeruje, że wkracza na teren autobiografizmu, równocześnie kpiąc z autobiografii: „zašto se ja zovem / branko? / pa to je valjda / jasno! / ali mogu ja / i o tome!" (dlaczego nazywam się / branko? / no to jest chyba / jasne! / ale mogę / i o tym! - BP, s. 54). Autorka Fragmentów romantycznej biografii ironiczne traktowanie siebie-realnego czy też siebie-persony oraz „demonizm wewnętrzny” uznaje za wyznacznik romantycznej skali wewnętrznego ,ja"23. Sytuując się wśród antropofagów Maleš drwi i prowokuje, dyskretnie nawiązując do założyciela japońskiej sekty Najwyższej Prawdy Aun Chizuo Matsumoto (Shoko Asahara), ale i innych szaleńców ${ }^{24}$.

„Ja" autoironicznego poety prezentuje konglomerat cech, które można odnosić do paradygmatu bohatera romantycznego: niepodważalny autobiografizm, patriotyczne i rewolucyjne zaangażowanie, odmienność, wyjątkowość realizowana w kilku rolach: pasterza, dziecka, kapłana-szamana, psychicznie chorego, błazna czy trickstera. Jung łączy obraz trickstera z karnawałową tradycją i odwróceniem porządku ${ }^{25}$. Błazeńsko-tricksterowska perspektywa oglądu rzeczywistości i prezentacji świata przedstawionego diametralnie odróżniają tę poezję od nurtu martyrologicznego. W twórczości reprezentanta semantycznego konkretyzmu ${ }^{26}$ odnajdujemy różnorodne sygnały odsyłające do konflik-

imię znaczy więcej, niż znaczyły imiona dotychczasowych bohaterów. Werter, René, Gustaw rysują swój portret i opowiadają swoje dzieje w taki sposób, iż czujemy, że za ich umownym powieściowym «ja» istotnie jakieś «ja» się kryje, choć czasem jesteśmy skłonni mieszać je ze swoim własnym. «Ja» jest sobą, bo ma własną historię, ma swój czas i swoje miejsce; wszystko to ma wewnątrz siebie" (s. 64). Maleš wzmacnia autobiograficzne nasycenie utworów pozostawiając bohaterowi własne imię.

${ }^{23}$ M. Piwińska, op. cit., s. 57-58.

24 Pisze o nich w swych monografiach J. Sieradzan. Idem, Szaleństwo w religiach świata, Kraków 2005 oraz Od kultu do zbrodni. Ekscentryzm i szaleństwo w religiach XX wieku, Katowice 2006.

25 A. Samuels, B. Shorter, F. Plaut, Krytyczny słownik analizy jungowskiej, przeł. W. Bobecki, L. Zielińska, s. 1, Wałbrzych 1994, s. 208.

26 C. Milanja, Dekonstrukcijska meštrija Branka Maleša, w: idem, Doba razlika, Zagreb 1991, s. 253. 
tu zbrojnego, lecz nacechowane są one niejednoznacznością ocen, oddaleniem od czarno-białych matryc, od mesjaniczno-ofiarniczej poetyki i estetyki. Trickster, praprzodek błazna, jest postacią ambiwalentną, łączy cechy boskie, ludzkie i zwierzęce, zatem i świat widziany jego okiem nie może przedstawiać czarno-białej rzeczywistości, z wyraźnymi podziałami, jasnymi zasadami i moralnością. Istotną jego cechą jest nieposzanowanie reguł społeczności, praw natury, łamanie zasad czy łączenie sprzeczności. Może być równocześnie mędrcem i głupcem, tworzyć i niszczyć, lecz przede wszystkim jest zawsze dzieckiem. Jako postać niejednoznaczna, ambiwalentna, półbóg, półczłowiek, półzwierzę podobnie do wampira znajduje się ,pomiędzy” i podobnie do romantycznego wieszcza jest pośrednikiem, mediatorem. Upiór i dziecko są egzystencjalnymi towarzyszami romantyka niezbędnymi dla jego właściwej edukacji sentymentalnej ${ }^{27}$. Bohater chorwackiego poety jest po trosze każdym z nich.

Pozycję dziecka mówiący podmiot wybiera w obliczu konfliktu: „kad su nas napali / ljudi od magnezija / bio sam / mali od bakra / sve je bilo / bakar!" (kiedy napadli nas / ludzie z magnezu / byłem / małym z miedzi / wszystko było / miedzią! - T, s. 20). W powyższym cytacie można się doszukiwać tych samych informacji, które przekazywała liryka zamieszczona w antologii U tom strašnom času. Jest w nim zarówno mowa o agresorach, jak i zaatakowanych i niepokonanych, jednak jest to wypowiedź, nasycona autoironią, a wielkiego bojownika zastępuje „mały”. Sygnały doświadczanej agresji są stłumione poprzez wkomponowanie ich w obrazowanie odwołujące się do wyobraźni i języka człowieka szalonego lub dziecka. Nieskażony przez cywilizację bohater, o którym marzyli romantycy, w swej łączności z naturą ocierający się o prymitywizm, w poezji Branka Maleša przemawia między innymi wyobraźnią dziecka i zachowaniem dziecka ${ }^{28}$, najbardziej pierwotnym sposobem poznawania świata: poprzez smakowanie, kosztowanie,

27 M. Piwińska, op. cit., s. 44.

${ }^{28}$ „Nasz wiek jest bardziej dzieckiem podszyty niż wypaloną, romantyczną młodością" - M. Piwińska, op. cit., s. 17. Dziecko Maleša nie posiada wszystkich cech charakteryzujących dziecko romantyczne, nie jest marzycielskie, blade, wątłe, niematerialne, nie rozpływa się (choć unosi) w powietrzu, ale jest autentyczne, naturalne, sytuuje się ,po stronie szaleństwa, ludu, baśni, romantyzmu i poezji” (ibidem, 
lizanie, charakterystyczne dla pierwszych miesięcy życia. Dziecięcość jawi się jako ratunek przed rzeczywistością i przed samym sobą, jako recepta na strach:

ja se plašim i ljuljam

dijete sebe

sve je to ništa, kažem

i penjem se uz štap

jer je gore nebo

a ja ти želim šaptati

a onda sam naglo miš

pjevam neke borbene pjesme

koje odmah zaboravljam (BP, s. 15) boję się i kołyszę

dziecko siebie

wszystko to nic, mówię

i wspinam się o lasce

bo w górze jest niebo

a ja chcę mu szeptać

a wtedy nagle jestem myszą

śpiewam jakieś waleczne pieśni

które od razu zapominam

Piwińska mówi o romantyku, że widzi świat dualistycznie, bo „jest go dwóch”29. Bohater wierszy Maleša jest równocześnie dzieckiem i starcem, myszą i bojownikiem oraz wylęknionym podmiotem pragnącym komunikacji z niebem. Płynnie przechodzi od dziecka do wodza. Na wzór romantycznego bohatera ,ja” liryków Maleša staje na szczycie, obejmuje przywództwo, a równocześnie pochyla się nad maluczkimi:

vodim!

mnogi plješću

tako prolazi život na

vrhu!

rijetko silazim $s$

himalaje

samo kad miš

s ruba sela

subotom zove upomoć! (BP, s. 51) prowadzę!

wielu oklaskuje

tak mija życie na

szczycie!

rzadko schodzę z

himalaji

tylko kiedy mysz

z krańca wsi

w sobotę wzywa pomocy!

s. 14). „Mimo że niewinne i nieświadome, jest już naznaczone piętnem wszystkich «piekielnych» chorób wieku" (ibidem, s. 31).

${ }^{29}$ M. Piwińska, op. cit., s. 67. 
Realizacja narcystycznej kliszy romantycznej wydaje się oczywista. Rodzi skojarzenia z obrazem Kordiana znajdującego się na szczycie Mont Blanc, tyle że z innego wiersza dowiemy się, że Himalaja to kobieta (BP, s. 68), a Maleš w swych autobiograficznych fragmentach błaznuje.

Poszukując tego, ,co radykalnie inne w stosunku do Zachodu (...) oraz ma walor prymitywizmu, sięga początków ludzkości i dlatego może być cenną alternatywą dla cywilizacji przeżywającej okresy kryzysu" ${ }^{30}$ romantycy zainteresowali się Orientem. Dla chorwackiego poety końca drugiego tysiąclecia „Orientem” stają się ,prymitywne” kultury czarnego lub czerwonego lądu. Toposy wskazujące na takie źródło inspiracji, po które Maleš sięga stosunkowo często, to wspomniany kanibalizm, szamanizm, specyficzny witalizm, zabawowość: „sada me zovu / malero! / to je dobro ime! / znači / poglavica apača / koji sjedi! / i ništa ne radi!" (teraz nazywają mnie malero! / to jest dobre imię! / oznacza / wódz apaczy / który siedzi! / i nic nie robi! - T, s. 21). Antropologia ponowoczesnego poety rozpoznaje pokrewieństwo osobowości dzisiejszej (własnej?) i osobowości „dzikiej”, nie skażonej cywilizacją. W poetyckich obrazach autor nie zamienia się $\mathrm{W}$ antropologa opisującego obce kultury, lecz przedstawiciela kultury własnej, w której - jak przystało na spadkobiercę romantycznego wieszcza - zajmuje on pozycję kapłana-szamana (udziela ślubu kapłance krów i białemu bykowi - T, s. 16; podaje recepty na osiągnięcie zdrowia, wyleczenie z szaleństwa i wszelkiego bólu - T, s. 18). Dysponując uszkodzonym instrumentarium, w kontaktach z niebem ponowoczesny szaman zdany jest na własny głos i jakże oszczędne komunikaty; zakończone wykrzyknieniami zdania ograniczone do dwóch wyrazów lub zastąpione niemal zwierzęcymi odgłosami. Dźwiękonaśladowcze sylaby odsyłają do zabiegów rytualnych oraz magicznych mocy języka i jakby przysłaniały semantyczne użycie słów, podobnie jak w kulturach „pierwotnych”, „prymitywnych”, „tubylczych”31.

30 M. Kuziak, Literatura dziewiętnastowieczna wobec Słowiańszczyzny, Orientu i Zachodu, w: Polonistyka w przebudowie, t. II, red. M. Czermińska, S. Gajda, K. Kłosiński, A. Legeżyńska, A. Z. Makowiecki, R. Nycz, Kraków 2005, s. 378.

31 W. J. Burszta, Od mowy magicznej do szumów popkultury, Warszawa 2009, s. 17. 
ou ou ou ou!

zovem nebo!

bubanj se pokvario!

ои ои ои оu! (T, s. 5) ou ou ou ou!

wołam niebo!

bęben się popsuł!

ou ou ou ou!

Błazen-szaman nie godzi się na jedną rolę - komika, nie rezygnuje z możliwości oddziaływania w społeczeństwie, choćby to oddziaływanie miało się dokonywać za pomocą magii - magii języka, poezji, śmiechu, zaklęcia? Kto jeszcze wierzy w moc i magię języka, poezji? Czy tylko szaman jest w stanie przywrócić tę moc? Wydziedziczony z tradycyjnej, wznoszącej ponad tłum pozycji wieszcza, przewodnika i rewelatora prawd wyższych, wspierając się na lasce (pasterskiej?) nadal niestrudzenie wspina się choćby na małe wzniesienie (brdašce - BP, s. 59) i przeskakuje z jednego wzgórza na drugie (T, s. 25). W narcystycznych gestach zdziecinniałego „wieszcza” rozpoznajemy schizofreniczne rozdarcie współczesnego poety. Właściwe dla mowy dziecka i dla schizofrenika niekoherencja, alogiczność, sprzeczność twierdzeń, pozwalają łączyć wiarę w możliwość szerszego społecznego oddziaływania sztuki (choćby w formie zabawiania) czy szerzej: wiarę w sztukę i poezję ze świadomością nieobecności początku, czyli podważeniem roli wypowiedzi i możliwości skonstruowania narracji: „ja uvijek počinjem od 9. rečenice” (zawsze zaczynam od 9 zdania BP, s. 12).

Na pozór autonomii romantycznej świadomości i panowania nad odczarowanym światem wskazuje Paul de Man. Dowodzi, że „romantycy są doskonale świadomi swego uwikłania w świat wpływów, który stanowi nieprzekraczalne wyzwanie dla ich indywidualności”, a oryginalną sygnaturę jednostka może pozostawić, posługując się ironią-,jedynym sposobem istnienia romantycznej podmiotowości”32. Chorwacki neoromantyk nie pozostawia wattpliwości, że posiada świadomość wpływu, informuje o niemożności dotarcia do początku historii/ opowieści/narracji (BP, s. 12).

32 Za: A. Bielik-Robson, Duch powierzchni. Rewizja romantyczna i filozofia, Kraków 2004, s. 18. 
Świadomość wpływu - wyjaśnia Agata Bielik-Robson sięgając do tekstów Blooma-łączy dwie prawdy: prawdę doświadczenia, pouczającą o istnieniu realnego świata zewnętrzego, oraz prawdę samowiedzy, pouczającą Ja o jego jednostkowej autonomii, wolności, swobodzie kreatywnej33.

Malešowe ,ja”, podobnie do ,ja” romantycznego, mając świadomość wpływu pragnie zachować szczególność, osobliwość, odnaleźć wolność w ramach zależności. Rekonstruując dzieje ludzkości, usiłuje wskazywać na indywidualne tropy, ,negocjuje” z wpływem, odsłaniając pierwotne zależności, pokazuje, jak odnaleźć wolność w ich ramach, w historię świata wpisuje wykreowane dzieje własnego rodu, a wszystko to nasącza głęboką ironią. Sięga do wyobrażeń o początku stworzenia, do naturalności i nagości pierwszych ludzi oraz do wyobrażeń plemiennego tańca wokół ogniska, choć sam ogień może być zastapiony przez symbol innych wartości dających szczęście, a nagość nie musi odsyłać do raju, lecz np. do „nieucywilizowanych” plemion bądź plemienia Maleš („maleš pleme!” - BP, s. 31).

Dokonując rewizji romantyzmu, Bielik-Robson przypomina stanowiska najbardziej znanych „rewizjonistów” tego okresu: pionierskie analizy Stanisława Brzozowskiego czy dekonstrukcyjne odczytania Paula de Mana. Brzozowski już na początku XX wieku pisał o zależności nowoczesnej podmiotowości od nieakceptowanego świata. Posługując się terminem ,przesilenie romantyczne”, wskazywał na „świadomość stałej obecności uwarunkowania Ja przez otaczający je «nieludzki» świat", a jedyną drogę wyjścia widział w zachowaniu, które zdominowało przywoływane tutaj zbiory poezji Branka Maleša - w ,heroicznym witalizmie i kulturalizmie, w pełni akceptującym uwarunkowanie jednostkowego Ja przez odczarowaną rzeczywistość"34. Zanurzenie się w to, co obce - a za takie uznać można opisywane przez poetę sceny wojenne czy kanibaliczno-wampiryczne - Brzozowski traktuje jako jedyny sposób na pokonanie obcości.

Maleš balansuje pomiędzy elementami wyobraźni, które odsyłają do źródeł romantycznych i ponowoczesnych. Zaangażowanie w czyn

\footnotetext{
33 Ibidem, s. 27-28.

34 Ibidem, s. 14-16.
} 
zbrojny miesza się z konsumpcjonizmem, rozumianym bardzo dosłownie i pokazanym obrazowo. Wojowanie i świętowanie (biesiada, taniec, śpiew) jawią się jako podstawowe formy zaangażowania człowieka dzisiaj i w przebiegu dziejów. Wspólna walka bywa zastępowana wspólną konsumpcją. Okresy zbiorowego konsumowania, świętowania - a sui generis świętem i karnawałem nazywana bywa przecież także wojna ${ }^{35}$ - odgrywają rolę integrującą (i różnicująca) oraz pełnią funkcję samookreślenia, komunikowania światopoglądu czy wyznawanych wartości. Transgresje prawa społecznego, z jakimi mamy do czynienia u Maleša, odświętność, obrzędowe formy Michael Bristol uznaje za najmocniej wzniecające poczucie solidarności i przynależności do wspólnoty ${ }^{36}$. Ilustracją wspólnego biesiadowania jest wiersz Ručak (Obiad), do kolektywnego spożywania zasiadają w nim wprawdzie osoby o różnych nazwiskach, jednak bliskie sobie. Śpiewają te same, wszystkim dobrze znane pieśni i same także świetnie wzajemnie się znają. Okazuje się bowiem, że są potomkami tych samych rodziców. Głównym posiłkiem w trakcie tego gromadnego posilania się jest gotowany i pieczony świat, a nóż (narzędzie kuchenne i narzędzie zbrodni) odgrywa rolę fajki pokoju. Po zakończonej uczcie uczestnicy rozchodzą się do wrogich obozów, by przystapić do wojny zaplanowanej w czasie obiadu: ,još smo onda isplanirali / jednu kišu i jedan rat (...) i otišli različitih imena / u razne šatore" (jeszcze wtedy zaplanowaliśmy / pewien deszcz i pewną wojnę (...) i o różnych imionach poszliśmy / do różnych namiotów - s. 82).

Poeta ironicznie nawiązuje do wspólnotowych idei z początku XIX wieku, podkreśla kulturową i genetyczną bliskość czy nawet rodzinne pokrewieństwo zwaśnionych stron, a równocześnie dialoguje z nurtem poezji wojennej z początku lat 90 . XX wieku. Upiór pełnił tam funkcję zbiorowego portretu wroga, tu zaś może być fantazmatem umożliwiającym kontakt z tym, co odrzucone, lecz własne, co obrzydliwe w nas samych, co Kristeva nazywa abjectem $^{37}$, a o czym w romantycznej biografii Marta Piwińska pisze, że rodziło się z miłości bliźniego, z chęci

35 R. Caillois, Żywioł i ład, przeł. A. Tatarkiewicz, Warszawa 1973, rozdział: Wojna $i$ sacrum.

36 Za: A. Bełkot, Konsumpcja jako kulturowo uwarunkowana forma przemocy, w: Formy przemocy w kulturze współczesnej, red. H. Mamzer, Poznań 2006, s. 20.

37 Comp. T. Kitliński, Obcy jest w nas. Kochać wedtug Julii Kristevej, Kraków 2001. 
ratowania duszy ludzkiej. Łamanie konwenansu, „niekulturalna agresywność romantycznych szaleńców i upiorów stąd pochodziła, że czuli się oni misjonarzami nowego «ja». [... chcieli ...] Wyzwolić ludzkie «ja» od ról społecznych, od ograniczeń rozumu, od upokorzeń ciała"38. Ponowoczesny wampir w wyobraźni autora nie wyłania się z grobu jedynie w czasie konfliktu zbrojnego. Maleš kreuje świat przypominający kanibaliczną, ucztującą, wzajemnie się konsumującą wspólnotę, przy czym jego bohater czerpie radość z tej formy bliskości z Drugim. Udokumentowane przypadki zjadania ludzkiego ciała, które przywołuje choćby Maria Janion w imponującej monografii Wampir. Biografia symboliczna, przerażają skalą wynaturzeń, tymczasem w błazeńskich kreacjach chorwackiego poety tracenie fragmentów własnego ciała jest z jednej strony ilustracją identyfikacyjnych dylematów osoby, z drugiej zaś - sposobem na dogłębne poznanie świata i człowieka. Poznanie angażujące całą jednostkę wraz z organami wewnętrznymi.

Ten oryginalny wojenny kanibalizm pozwala w ponowoczesnym upiorze doszukiwać się zwampiryzowanego oblicza współczesnego konsumenta, skażonego nieustannym spożywaniem i nietrwałością. „Utymczasowieniu” podlega wszystko, co łączone jest z wyborami na stałe (wiara, państwo, żona): „bogove i žene izabirem svaki dan iznova" (bogów i kobiety/żony wybieram codziennie od nowa - s. 8). Wyznanie to brzmi jak maksyma idealnego konsumenta, jak uczy bowiem Zygmunt Bauman:

Najlepiej by konsument nie chwytał się niczego mocno; nic nie powinno nakazywać zobowiązania na zawsze, żadnych potrzeb nie należy postrzegać jako w pełni zaspokojonych, żadnych pragnień nie wolno uznawać za ostateczne. Każdą przysięgę lojalności czy jakiekolwiek zobowiązanie powinno się zaopatrzyć w klauzulę «ważne do odwołania». Tym, co się liczy, jest zmienność, wbudowana tymczasowość wszystkich zobowiązań; liczy się ona bardziej niż samo zobowiązanie, które nie powinno trwać dłużej niż do chwili skonsumowania obiektu pożądania (lub utraty przez ów obiekt powabu) $)^{39}$.

38 M. Piwińska, op. cit., s. 60.

39 Z. Bauman, Praca, konsumpcjonizm i nowi ubodzy, Kraków 2006, s. 56. 
W społeczeństwie konsumentów, użytkowników, w dobie wypierania sztuki wymagającej, poeta nie znajduje dla siebie miejsca w świecie. Uciekając w chorobę czy szaleństwo korzysta z jeszcze jednej możliwości nawiązania do romantycznego paradygmatu. Dawno pozbawiony romantycznego dziedzictwa ratuje się niedojrzałością, odgrywanym niezrozumieniem i kurczowym trzymaniem się narcystycznych pozycji. Na wzór romantycznej osobowości ucieleśnia pierwiastek religijny i rewolucyjny (anarchiczny), wspina się ku niebu i śpiewa rewolucyjne pieśni, ale natychmiast je zapomina. Ponowoczesny romantyk jest bowiem skażony konsumpcyjną tymczasowością, wszystkie role odgrywa przez krótką chwilę. Po konsumencku żadnej z nich nie przyjmuje na stałe i na poważnie. Zachłannie smakując świat, przybiera przedziwną monstrualną postać schizofrenicznego tricstera kanibala, usiłującego dokonać niemożliwego: rozeznać się w świecie z dwoma, trzema ... $\mathrm{z}$ bezlikiem centrów:

a sela se skupljaju

oko središta

kojih ima dva, tri bezbroja

pa opet moram računati (s. 15) a wsie skupiają się wokół centrum

które są dwa, trzy bezliki i znów muszę liczyć

Chętnie przywoływane motywy wampiryczne u Branka Maleša i w antologii $W$ tej strasznej chwili mają diametralnie różne zadania. Maleš wskazuje dzięki nim na ambiwalencje natury człowieka, na jego usytuowanie na pograniczu, wprowadza (auto)ironiczną, błazeńską, tricksterowską i dekonstrukcyjną perspektywę. W antologii motywy te służyły kreowaniu jednoznacznego, czarno-białego świata moralnego, wiodąc ku kiczowatej upiorności. Ukazywały rzeczywistość skontrastowaną, niewinność i czystość po jednej stronie oraz zezwierzęcenie i potworność obejmujące nawet fizjonomię strony przeciwnej. W obu realizacjach można się doszukiwać romantycznych inspiracji, jednak wyrastają one z odmiennych przesłanek. W nurcie martyrologicznym z narodowo-odrodzeniowej dziewiętnastowiecznej chorwackiej propedeutyki wiedzy o społeczeństwie, zaś u ludycznego Maleša demonizm bohatera sprzężony z hedonizmem wskazuje na możliwe inspiracje 
niesamowitością romantycznej fantastyki i równoczesną jej dekonstrukcję. Maleš bliższy jest romantycznej idei imaginacji i ignorowania politycznych i społecznych realiów. Jego poezja staje się świadectwem niezgody na dyktat „poważnych czasów”40. Różnorodność romatycznych śladów w chorwackiej poezji końca XX wieku uznać należy za logiczną konsekwencję wewnętrznego rozwarstwienia samego chorwackiego romantyzmu, w którym ponadnarodowy romantyzm występował obok ruchu iliryjskiego i odrodzenia narodowego. Sama zaś postać wampira we współczesnej chorwackiej poezji nie oznacza aktualizacji wzorców chorwackiej kultury wysokiej, lecz również jej otwarcie na inspiracje płynące kanałami kultury popularnej.

\section{Literatura}

Bauman Z., Praca, konsumpcjonizm i nowi ubodzy, Kraków 2006.

Bielik-Robson A., Duch powierzchni. Rewizja romantyczna i filozofia, Kraków 2004.

Burszta W. J., Od mowy magicznej do szumów popkultury, Warszawa 2009.

40 To aluzja do wiersza Slavka Mihalicia Majstore, ugasi svijeću, który dwukrotnie ukazał się w polskim przekładzie. Comp. S. Mihalić, Mistrzu zgaś świecę, w: idem, Sen w świetle, wybór, przekład i wstęp J. Kornhauser, Warszawa 1980, s. 61; S. Mihalić, Mistrzu zgaś świecę, w: idem, Okna szaleństwa, wybór i przekład G. Łatuszyński, Warszawa 2006, s. 71. Powyższy cytat został zapisany w przekładzie filologicznym, a jego oryginalne brzmienie ozbiljna vremena przez obu wymienionych thumaczy w literackim przekładzie oddane jest jako „ciężkie czasy”. W utworze Mihalić odwołuje się do dwóch paradygmatów: romantycznego Autora-Geniusza, który jednak w wierszu jest obecny jedynie jako milcząca postać, oraz błazeństwa. Malešovi bliższa jest druga strategia, pozwalająca na mówienie/pisanie ze świadomością niemożności osiągnięcia ostatecznego sensu czy wypowiedzenia ,pierwszego zdania”. Woli przewrotnego, nawet kłamliwego błazna i oszustwo oraz zabawę niż milczącego mistrza i proroka. Na temat wspomnianego wiersza Mihalicia, zajmującego wyjątkową pozycję w chorwackiej poezji lat 70., comp. A. Stamać, Tko govori majstoru, w: Suvremeno hrvatsko pjesništvo, red. A. Stamać, Zagreb 1988; B. Czapik-Lityńska, Ku postmodernizmowi. Problem zmiany ideowo-estetycznej w latach siedemdziesiatych, w: Chorwacja lat siedemdziesiatych XX wieku. Kultura - język - literatura, red. L. Małczak, P. Pycia, Katowice 2010, s. 111; T. Vuković, Uciszony głos mistrza. Polityka poetyk chorwackiej poezji lat siedemdziesiatych XX wieku, przeł. P. Pycia, w: Chorwacja lat siedemdziesiatych XX wieku..., op. cit., s. 94-107. 
Caillois R., Żywioł i ład, przeł. A. Tatarkiewicz, Warszawa 1973.

Dyras M., Re-inkarnacje narodu. Chorwackie narracje tożsamościowe w latach dziewięćdziesiatych XX wieku, Kraków 2009.

Chorwacja lat siedemdziesiatych XX wieku. Kultura-język-literatura, red. L. Małczak, P. Pycia, Katowice 2010.

Formy przemocy w kulturze wspótczesnej, red. H. Mamzer, Poznań 2006.

Janion M., Niesamowita Słowiańszczyzna, Kraków 2006.

Janion M., Wampir. Biografia symboliczna, Gdańsk 2008.

Kitliński T., Obcy jest w nas. Kochać wedtug Julii Kristevej, Kraków 2001.

Kornhauser J., Chorwacka poezja martyrologiczna po 1991 roku i stereotypy narodowe, w: idem, Świadomość regionalna i mit odrębności (o stereotypach w literaturze serbskiej i chorwackiej), Kraków 2001.

Kuziak M., Literatura dziewiętnastowieczna wobec Stowiańszczyzny, Orientu i Zachodu, w: Polonistyka w przebudowie, t. II, red. M. Czermińska, S. Gajda, K. Kłosiński, A. Legeżyńska, A.Z. Makowiecki, R. Nycz, Kraków 2005.

Maleš B., »biba posavec«, Zagreb 1996.

Maleš B., Trcikster, Zagreb 1997.

Milanja C., Doba razlika, Zagreb 1991.

Oraić Tolić D., Književnost i sudbina, Zagreb 1995.

Piwińska M., Złe wychowanie. Fragmenty romantycznej biografii, Warszawa 1981.

Rapacka J., Godzina Herdera. O Serbach, Chorwatach i idei jugostowiańskiej, Warszawa 1995.

Samuels A., Shorter B., Plaut F., Krytyczny stownik analizy jungowskiej, przeł. W. Bobecki, L. Zielińska, s. 1, Wałbrzych 1994.

Sieradzan J., Od kultu do zbrodni. Ekscentryzm i szaleństwo w religiach XX wieku, Katowice 2006.

Sieradzan J., Szaleństwo w religiach świata, Kraków 2005.

Słownik literatury polskiej XIX wieku, red. J. Bachórz, A. Kowalczykowa, Wrocław -Warszawa - Kraków 1994.

U ovom strašnom času, red. I. Sanader, A. Stamać, Split 1992.

$W$ tej strasznej chwili. Antologia współczesnej wojennej liryki chorwackiej, red. I. Sanader, A. Stamać, przeł. M. Kordowicz, Warszawa 1996. 